\title{
YAC Contigs of the Rabl and wobbler (wr) Spinal Muscular Atrophy Gene Region on Proximal Mouse Chromosome 11 and of the Homologous Region on Human Chromosome $2 p$
}

\author{
Niels Wedemeyer, Andreas lengeling, Melanie Ronsiek, DiRk Korthaus, Kristin Baer, \\ MARTINA WUTTKE, AND HARALD JOCKUSCH
}

Developmental Biology Unit, W7, University of Bielefeld, D-33501 Bielefeld, Germany

Received October 9, 1995; accepted January 10, 1996

\begin{abstract}
Despite rapid progress in the physical characterization of murine and human genomes, little molecular information is available on certain regions, e.g., proximal mouse chromosome 11 (Chr 11) and human chromosome $2 p$ (Chr 2p). We have localized thewobbler spinal atrophy gene wr to proximal mouse $\mathrm{Chr}$ 11, tightly linked to Rabl, a gene coding for a small GTP-binding protein, and GInsps1, an intronless pseudogene of the glutamine synthetase gene. We have now used these markers to construct a 1.3-Mb yeast artificial chromosome (YAC) contig of the Rabl region on mouse Chr 11. Four YAC clones isolated from two independent YAC libraries were characterized by rare-cutting analysis, fluorescence in situ hybridization (FISH), and sequence-tagged site (STS) isolation and mapping. Rabl and GIns-psl were found to be only $\mathbf{2 0 0}$ kb apart. A potential CpG island near a methylated Narl site and a trapped exon, ETG1.1, were found between these loci, and a new STS, AHY1.1, was found over 250 kb from Rabl. Two overlapping YACs were identified that contained a $150-k b$ region of human $\mathrm{Chr} 2 \mathrm{p}$, comprising the RAB1 locus, AHY1.1, and the human homologue of ETG1.1, indicating a high degree of conservation of this region in the two species. We mapped AHY1.1 and thus human RAB1 on Chr 2p13.4-p14 using somatic cell hybrids and a radiation hybrid panel, thus extending a known region of conserved synteny between mouse Chr 11 and human Chr 2p. Recently, the gene LMGMD2B for a human recessive neuromuscular disease, limb girdle muscular dystrophy type 2B, has been mapped to 2p13p16. The conservation between the mouse Rabl and human RAB1 regions will be helpful in identifying candidate genes for the wobbler spinal muscular atrophy and in clarifying a possible relationship between wr and LMGMD2B. ๑ 1996 Academic Press, Inc.
\end{abstract}

\section{INTRODUCTION}

The construction of yeast artificial chromosome (YAC)based physical maps of genomic regions, in conjunction with chromosomal mapping based on segregation, is a

\footnotetext{
${ }^{1}$ To whom correspondence should be addressed. Fax: +49 (521) 1065654.
}

powerful tool to advance the identification of gene complexes and of disease genes. In this respect, the analysis of human chromosomes 16 and 19 (Nowak, 1995) and mouse chromosomes 1 (Hunter et al., 1994) and 17 (Cox et al., 1993) as well as of human and murine X chromosomes is particularly far advanced (Hamvas et al., 1993). On the other hand, such extensive information is not available for mouse proximal chromosome 11 (Chr 11) and human chromosome 2p (Chr 2p) (Fig. 1; cf. Berry \& al., 1995; Nowak, 1995), known to share at least thegenes for the reticuloendotheliosis oncogene (Brownell et al., 1985), for a brain-specific $\beta$-spectrin isoform (Bloom et al., 1992), and for cytoplasmic malate dehydrogenase (Ball \& al., 1994). However, comparing the segregation map of the mouse with the human cytogenetic map, a colinear relationship cannot be established: The positions of the reticuloendotheliosis oncogene and spectrin gene appear to be interchanged between the two species (Fig. 1).

In the mouse, this region was further characterized by being shown to contain Rab1, a gene coding for a small GTP-binding protein, and GIns-ps1, a glutamine synthetase pseudogene (Wichmann et al., 1992). Our interest in this chromosomal region relates to the investigation of a mouse spinal muscular atrophy mutation, wobbler (wr; Duchen and Strich, 1968), which we have localized to proximal Chr 11 (Kaupmann et al., 1992). This localization has led to the consideration and exclusion of several candidategenes and theidentification of human Chr $2 p$ as the region in which the homologue of wr should be located (Kaupmann et al., 1991; Lengeling et al., 1994). At present, there are three genes for which no recombination with the wr locus has been found among 54 backcross animals showing the wobbler (WR) phenotype: Rab1, GIns-ps1 (Wichmann et al., 1992), and Mor2 (Korthaus et al., 1996).

Here, we report on the construction and characterization of a 1.3-Mb mouse YAC contig comprising, in addition to Rabl and GIns-ps1, a novel trapped exon ETG1.1. Human RAB 1 was mapped to $C h r 2 p$ and used to construct a 1.2-M b YAC contig for detailed homology studies. 


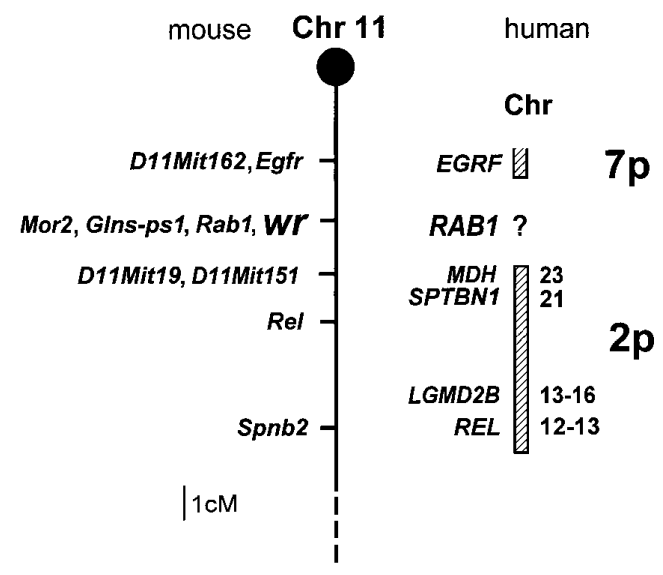

FIG. 1. The genetic map around the Rabl/wr locus on proximal mouse Chr 11 and homologous regions on human Chr 7 and Chr 2. Gene symbols Egfr/EGFR, epidermal growth factor receptor; Mor2/ $\mathrm{MDH}$, cytoplasmic malate dehydrogenase; GIns-ps1, glutaminesynthetase pseudogene 1; Rab1/RAB1, ras-related protein 1; Rel/REL, reticuloendotheliosis oncogene; Spnb2/SPTBN1, brain-specific isoform of $\beta$ spectrin; wr, wobbler; LGMD2B, limb girdle muscular dystrophy type $2 \mathrm{~B}$. For references see the Introduction.

\section{MATERIALS AND METHODS}

YAC library screening and DNA preparation. Murineand human YACs were isolated from three different genomic libraries constructed at MIT (Kusumi et al., 1993) and ICRF (two libraries: Larin et al., 1991; S. Meier-E wert, unpublished). The ICRF libraries were screened by hybridization with a $0.87-k b$ cDNA fragment representing the 3 '-nontranslated region of the Rab-1 mRNA (Wichmann et al., 1989). The MIT library was screened using PCR assays of a hierarchy of pooled DNA samples (Green and Olson, 1990). The loci and primer sequences used for PCR screening as well as the PCR conditions are listed in Table 1.

YAC clones were grown in AHC medium (deficient in uracil and tryptophan), and their DNAs were isolated according to standard methods (Polaina and Adam, 1991). Total yeast DNA was prepared in agarose plugs using a lithium dodecyl sulfate method (Anand and Southern, 1990).

Restriction digest YAC mapping. Restriction maps of the YACS were generated by digestion with rare-cutting restriction endonucleases. YACs were digested by incubating the agarose plugs with 30 units of enzyme (Gibco BRL) for $2 \mathrm{~h}$ under conditions recommended by the manufacturer. Fragments were sized using a rotating field electrophoresis system (Rotaphor, Biometra) on 1\% agarose (Gibco $B R L), 0.25 \times$ TBE pulsed-field gels using the following switching times: 5 to $90 \mathrm{~s}$ (lin ramp), 120 to $180^{\circ} \mathrm{C}$ (log ramp), 120 to $180 \mathrm{~V}$ (log ramp), $13^{\circ} \mathrm{C}$ for $37 \mathrm{~h}$.

Southern blots were hybridized with pBR322 fragments corresponding to the PYAC4 right (URA arm probed with the 1.7-kb Pvulland BamHI-digested fragment) and left (TRP arm probed with the 2.7-kb Pvul I- and BamHI-digested fragment) vector arms. The GIns and Rabl probes were prepared as described (Bhandari et al., 1988; Wichmann et al., 1989).

IRS probe generation. Interspersed repetitive sequence polymerase chain reaction (IRS-PCR) was carried out on YAC miniprep DNA, using a B1 (left) primer (ACTCAGAAATCYRCCTGCCTCTGCCTC; Schalkwyk, London, pers. comm., 1994) for murine and an Alu-3'primer (CACCTGAGGTCAGGAGTTC; Bates et al., 1992) for human clones. The PCR cycler (TRIO Thermocycler, Biometra) conditions were 1 cycle at $94^{\circ} \mathrm{C}$ for $4 \mathrm{~min}$ and 35 cycles at $68^{\circ} \mathrm{C}$ (B1) or $52^{\circ} \mathrm{C}$ (Alu) for $1 \mathrm{~min}, 72^{\circ} \mathrm{C}$ for $3 \mathrm{~min}$, and $90^{\circ} \mathrm{C}$ for $1 \mathrm{~min}$. $3^{\prime}$-Overhanging nucleotides were removed by Pfu DNA polymerase treatment (PCR Polishing Kit, Stratagene) followed by phosphorylation using T4 kinase (Gibco BRL). Blunt-ended PCR products were cloned into a Smal-digested pUC 18. To create new sequence-tagged sites (STS), cloned IRS-PCR products were sequenced with pUC 18-specific primers using a T7 DNA sequencing kit (Pharmacia).

I solation of YAC end fragments. End rescues were carried out by an inverted PCR described as genomic end rescue PCR (Silverman et al., 1989). One microgram of YAC miniprep DNA was digested with either EcoRV or HaelI, followed by circularization under standard ligation conditions. Subsequently, PCR with pYAC4-specific inverted primers was performed with 50 pmol of each primer, 150 ng circularized DNA, 3 units Taq DNA polymerase (Promega), nucleotides, and buffer (as recommended by the supplier) in a total volume of $50 \mu \mathrm{l}$. After the first denaturation $\left(94^{\circ} \mathrm{C}\right.$ for $\left.4 \mathrm{~min}\right), 35$ cycles of annealing $\left(62^{\circ} \mathrm{C}\right.$ for $\left.1 \mathrm{~min}\right)$, extension $\left(72^{\circ} \mathrm{C}\right.$ for $\left.2 \mathrm{~min} 30 \mathrm{~s}\right)$, and denaturation $\left(90^{\circ} \mathrm{C}\right.$ for $\left.1 \mathrm{~min}\right)$ were performed. PCR products were cloned into a Smal-digested pUC18 and sequenced as described above.

Exon trapping. YAC ymWIBR141E 1 was isolated from the host yeast by PFGE in LMP-agarose (Gibco BRL) and simultaneously digested with 90 units of Bgl II and BamHI. After purification with GeneClean (BIO 101), the DNA was cloned into the PSPL1 vector at the BamHI site. Plasmid DNA was prepared by alkalinelysis purified on Qiagen columns and used to transfect COS-7 cells. Cytoplasmic RNA isolation, first-strand CDNA synthesis, and PCR amplification were performed according to Buckler et al. (1991). The resulting PCR products were cloned in pUC18 and sequenced as described above for STS generation.

Fluorescence in situ hybridization (FISH). Chromosome spreads were prepared from the WMP mouse cell line, in which all autosomes except Chr 19 are present as metacentric Robertsonian translocations. B1-PCR products of the YACs were labelled with biotin-11UTP by nick-translation (Bio-Nick Labeling System, Gibco BRL). The probes were preannealed with mouse Cot-1 DNA (Sigma) to suppress the hybridization of repetitive sequences. Hybridization with $100 \mathrm{ng}$ labelled DNA in $20 \mathrm{ml} \mathrm{mix}$ per slide was performed at $37^{\circ} \mathrm{C}$ for $15 \mathrm{~h}$. After in situ hybridization and washing procedures, signals were detected with avidin-FITC and anti-avidin-antibody (Vector). Chromosomes were stained with DAPI $(1 \mathrm{mg} / \mathrm{ml})$ and propidium iodide $(0.5 \mathrm{mg} / \mathrm{ml})$. These experiments were performed in collaboration with Dr. Hameister and C. Klett (UIm).

Cell hybrid mapping. For the chromosomal localization of the human RAB1 gene, a Rab1 mouse CDNA subfragment was hybridized to BamHI-digested DNA from 20 human/rodent somatic cell hybrids (Bios Laboratories, New Haven, CT). Subchromosomal localization was determined using total chromosome 2 (NA 108268) and the deletion derivatives GM 11172 and NA 11444 (Coriell Cell Repositories, Camden, NJ ), representing the long and the short arm of Chr 2, respectively.

For a more detailed mapping, the GeneBridge 4 radiation hybrid mapping panel (Research Genetics, Huntsville, AL) was used. This panel represents 91 (radiation hybrid) clones of the whole human genome (Walter et al., 1994).

\section{RESULTS}

Isolation and characterization of mouseYACs. Two markers, Rab1 and GIns-ps1, known to be closely linked to the wobbler (wr) locus on proximal mouse Chr 11 (Kaupmann et al., 1992; Wichmann et al., 1992), were used to identify YAC clones derived from that region by screening a total of 40,000 clones in three independent libraries. Using PCR screening to detect a $5^{\prime}$ microsatellite of the GIns-ps1 pseudogene, a 650kb YAC, ymWIBR141E 1, was identified in the MIT/ Whitehead mouse YAC library (Kusumi et al., 1993). A PCR-based screening for a STS from the $3^{\prime}$-UTR of Rabl detected a 320-kbYAC, ymWIBR 168H 4, that was shown to also contain GIns-ps1, thus confirming the close genetic (Wichmann et al., 1992) and physical (Meyer-Kleine and J ockusch, unpublished) linkage of 
TABLE 1

PCR Primers for STS from the Rab1/RAB1 Regions

\begin{tabular}{|c|c|c|c|c|}
\hline STS & Sequence $\left(5^{\prime}-3^{\prime}\right)$ & $\begin{array}{l}\text { Size } \\
\text { (bp) }\end{array}$ & Annealing & Reference \\
\hline D11Mit79 & $\begin{array}{l}\text { TTCTTGGTCGTAGCCCTCAC } \\
\text { GACACACAACACCTCGCG }\end{array}$ & 152 & $62^{\circ} \mathrm{C}$ & MIT \\
\hline Glns-ps1 & $\begin{array}{l}\text { AGCTTTGGAGACAACAATTAGATC } \\
\text { TGTTCATCAGCTGAGGAATGGATG }\end{array}$ & 181 & $60^{\circ} \mathrm{C}$ & Bhandari et al. (1989) \\
\hline Rab1 & $\begin{array}{l}\text { GTACTACCTGCTAAACCGTAGGC } \\
\text { CTTTCCTGGCCTGCTGTGTCC }\end{array}$ & 246 & $60^{\circ} \mathrm{C}$ & Wichmann et al. (1990) \\
\hline BY 1.1 & $\begin{array}{l}\text { CCATACCTTCTGCTGGAGGTATAC } \\
\text { CTAGTAGTTGCTCAGTCCCATGAG }\end{array}$ & 185 & $70^{\circ} \mathrm{C}$ & This work \\
\hline BY 1.2 & $\begin{array}{l}\text { CTTCTCTGGTTTTGTAGG } \\
\text { CCATTGAGCCTCCTCTATC }\end{array}$ & 62 & $52^{\circ} \mathrm{C}$ & This work \\
\hline ETG1.1 & $\begin{array}{l}\text { GACAGCTGCTCCATGCGTCC } \\
\text { GAGTCAGTTGTCTGAAAAATGCAG }\end{array}$ & 114 & $56^{\circ} \mathrm{C}$ & This work \\
\hline YIL & $\begin{array}{l}\text { CTGTTAGTAGGAAGCAAGGTCTC } \\
\text { GATCGCGTAGTCGATAGTGGC }\end{array}$ & 104 & $66^{\circ} \mathrm{C}$ & This work \\
\hline BY2.1 & $\begin{array}{l}\text { CCTGACCCACTTTCCTACATC } \\
\text { GTAGCTGACCTTCTAGTCTTTG }\end{array}$ & 450 & $64^{\circ} \mathrm{C}$ & This work \\
\hline BY 2.3 & $\begin{array}{l}\text { CTCTAGCAGAGGACCCAGGTTC } \\
\text { CTGAAAGTGCCGACTACTGTCG }\end{array}$ & 230 & $68^{\circ} \mathrm{C}$ & This work \\
\hline AHY 1.1 & $\begin{array}{l}\text { CAGGCTAAGCTGCCTCTGAC } \\
\text { GACAGCTTTTCAGAGCTACTCC }\end{array}$ & 270 & $65^{\circ} \mathrm{C}$ & This work \\
\hline
\end{tabular}

Note Size, size of the amplification product using C57BL6/] DNA.

Rab1 and GIns-ps1. By hybridization screening with a CDNA Rabl probe, two positive YACs were detected among 5000 clones of the ICRF mouse YAC library (S. Meier-E wert, unpublished): $903 \mathrm{~A} 0745(550 \mathrm{~kb})$ and 903H 082 (1100 kb). Both lacked GIns-ps1 sequences.

These four mouse YAC clones were tested for chimerism by FISH to mouse metaphase chromosomes and by restriction analysis. The 650-kb YAC, ymWIBR 14IE 1, was chimeric according to FISH analysis, as hybridization signals were seen on Chr 11 and proximal Chr X. The other three YACs appeared non- chimeric, as they gave a signal only on proximal $\mathrm{Chr}$ 11 (Table 3).

Restriction analysis was performed using six rarecutting restriction nucleases and probes for the "left end" (pBR322, $2.7 \mathrm{~kb})$ and "right end" (pBR322, $1.7 \mathrm{~kb})$ inserts, for theSTSs ETG1.1 and AHY1.1, and for GInsps1 and Rab1 (Fig. 2, Table 2). Extensive overlap of the restriction patterns allowed for the construction of $\mathrm{a} \geqslant 1.3-\mathrm{Mb}$ contig (Fig. 3), considering that the left arm of YAC ymWIBR 141E 1 is not derived from Chr 11 . The distance between GIns-ps1 and Rabl, which are both

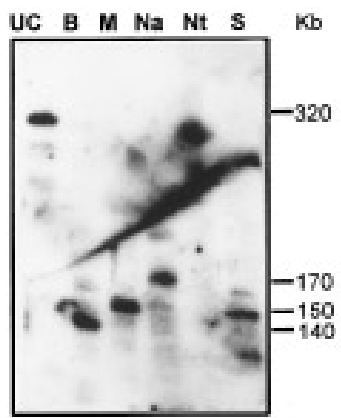

a

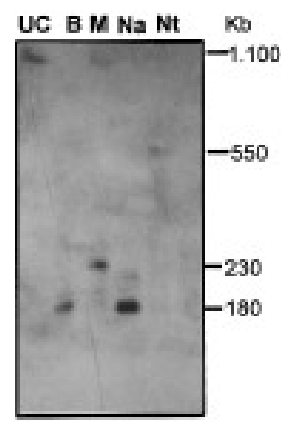

b

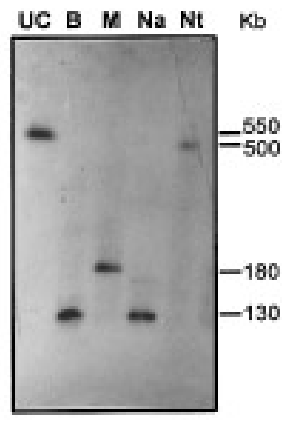

C

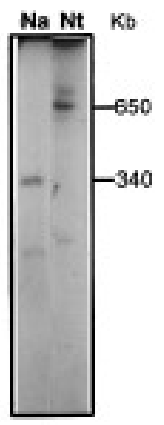

d

FIG. 2. Rare-cutter restriction patterns of the mouse Rabl region on Chr 11. Pulsed-field gel electrophoresis (PFGE) of three different YAC clones ((a) ymWIBR168H4; (b) 903H082; (c) 9030745) and genomic DNA ((d) C57BL/6 kidney). UC, uncut; B, BssHII; M, Mlul; Na, $\mathrm{Narl}$; Nt, Notl; S, Sfil. Hybridization patterns with the Rabl probe are shown as examples. The grouping of fragment sizes in a around $160 \mathrm{~kb}$ indicates CpG islands. Comparison of $\mathbf{b}$ and $\mathbf{c}$ shows common fragments. Comparison of $\mathbf{b}$ and $\mathbf{c}$ with $\mathbf{d}$ shows smaller Notl fragments in YAC than in genomic DNA, indicating a Notl site near GIns-ps1 in the genomic DNA. Comparison of $\mathbf{a}, \mathbf{b}$, and $\mathbf{c}$ with $\mathbf{d}$ shows smaller Narl fragments in YACs than in genomic DNA, indicating methylation of a cleavage site in the latter. 
TABLE 2

YACs from the Rab1/RAB1 Regions and Their Rare-Cutter Restriction Fragments

\begin{tabular}{|c|c|c|c|c|c|c|c|c|c|}
\hline Species & YAC & Size & Probe & BssHII & Mlul & Narl & Notl & Nrul & Sfil \\
\hline $\begin{array}{l}\text { Mouse } \\
\text { (MIT) }\end{array}$ & ymWIBR141E 1 & 650 & $\begin{array}{l}\text { Left arm } \\
\text { Right arm } \\
\text { Glns }\end{array}$ & $\begin{array}{l}280 \\
270 \\
270\end{array}$ & $\begin{array}{l}280 \\
150 \\
150\end{array}$ & $\begin{array}{c}140 \\
/ \\
170\end{array}$ & $\begin{array}{l}650 \\
650 \\
650\end{array}$ & & $\begin{array}{r}150 \\
60 \\
140\end{array}$ \\
\hline$(\mathrm{MIT})$ & ymWIBR $168 \mathrm{H} 4$ & 320 & $\begin{array}{l}\text { Left arm } \\
\text { Right arm } \\
\text { Glns } \\
\text { Rab1 }\end{array}$ & $\begin{array}{l}130 \\
140\end{array}$ & $\begin{array}{l}150 \\
130 \\
150 \\
150\end{array}$ & $\begin{array}{c}150 \\
5 \\
/ \\
170\end{array}$ & $\begin{array}{l}320 \\
320 \\
320 \\
320\end{array}$ & $\begin{array}{l}150 \\
120 \\
110 \\
150\end{array}$ & $\begin{array}{r}90 \\
20 \\
110 \\
150\end{array}$ \\
\hline (ICRF) & $903 \mathrm{H} 082$ & 1100 & $\begin{array}{l}\text { Left arm } \\
\text { Right arm } \\
\text { Rab1 } \\
\text { AHY 1/1 }\end{array}$ & $\begin{array}{r}130 \\
95 \\
150 \\
50\end{array}$ & $\begin{array}{r}130 \\
110 \\
200 \\
60\end{array}$ & $\begin{array}{r}130 \\
80 \\
150 \\
110\end{array}$ & $\begin{array}{r}600 \\
90 \\
600\end{array}$ & $\begin{array}{l}160 \\
150\end{array}$ & $\begin{array}{c}130 \\
90 \\
/ \\
110\end{array}$ \\
\hline (ICRF) & 903A0745 & 550 & $\begin{array}{l}\text { Left arm } \\
\text { Right arm } \\
\text { Rabl }\end{array}$ & $\begin{array}{l}130 \\
100 \\
130\end{array}$ & $\begin{array}{l}130 \\
120 \\
180\end{array}$ & $\begin{array}{r}130 \\
90 \\
130\end{array}$ & $\begin{array}{r}550 \\
50 \\
500\end{array}$ & 160 & $\begin{array}{l}1 \\
1 \\
1\end{array}$ \\
\hline $\begin{array}{l}\text { Human } \\
\quad \text { (ICRF) }\end{array}$ & 900A0894 & 1000 & $\begin{array}{l}\text { Left arm } \\
\text { Right arm } \\
\text { Rab1 } \\
\text { AHY1.1 }\end{array}$ & & $\begin{array}{r}90 \\
110 \\
150 \\
150\end{array}$ & & $\begin{array}{r}230 \\
70\end{array}$ & $\begin{array}{l}280 \\
210 \\
170\end{array}$ & \\
\hline (ICRF) & 900F 0982 & 600 & $\begin{array}{l}\text { Right arm } \\
\text { Left arm } \\
\text { Rab1 } \\
\text { AHY } 1.1\end{array}$ & & $\begin{array}{r}90 \\
380 \\
180 \\
180\end{array}$ & & $\begin{array}{l}230 \\
210\end{array}$ & $\begin{array}{l}150 \\
350 \\
150\end{array}$ & \\
\hline
\end{tabular}

Note. Blank space, not done; /, not detected.

contained in YAC ymWIBR 168H4, was determined to be $200 \mathrm{~kb}$ (Fig. 3).

Correlation to the genomic physical map. Whereas the small physical distance between Rabl and GInsps1 confirmed previous genetic and physical evidence, there are two inconsistencies between the YAC map and the genomic restriction map. First, Rabl was found on a 650-kb Notl fragment of a genomic digest (MeyerKleine and J ockusch, unpublished). This would have to extend for about $240 \mathrm{~kb}$ into the right arm of ymWIBR141E1. However, no Notl site was found in this YAC. In accordance with the FISH result, this argues for a chimerism of this YAC, with the fusion site close to the overlap with the right arm of ymWIBR168H4. This would define the length of the Chr 11 YAC contig as about 1.3 Mb, i.e., the minimum length given above (Fig. 3).

Another discrepancy between the restriction pattern

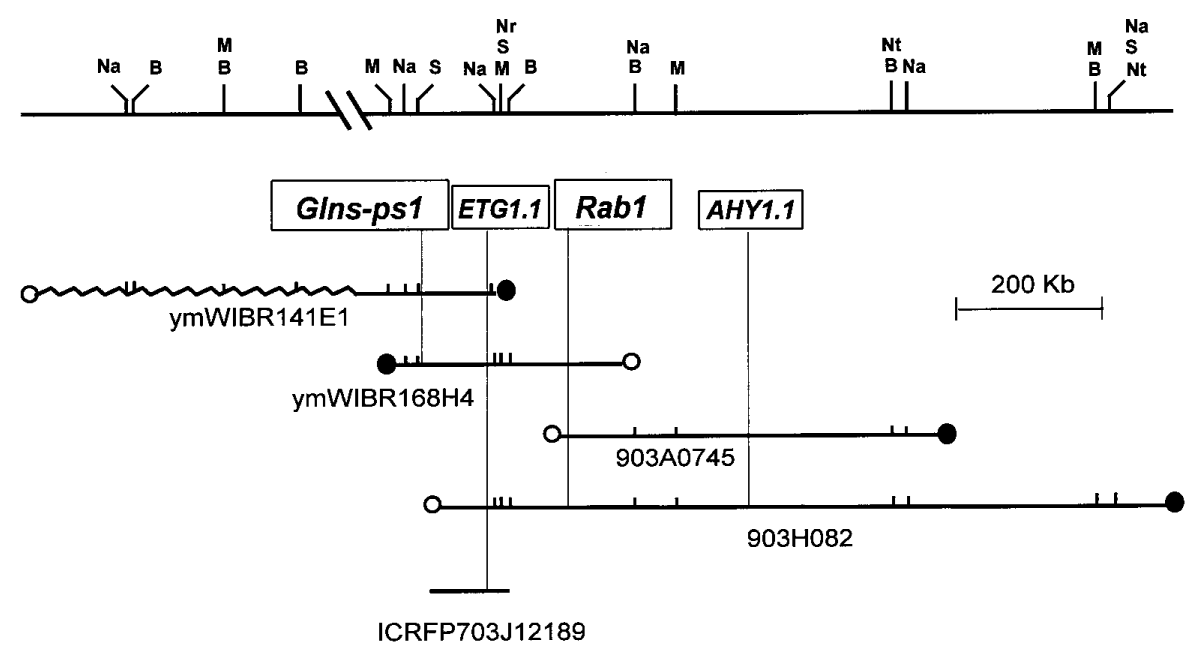

FIG. 3. Mouse YAC contig and rare-cutting restriction map around the Rabl gene on Chr 11. Restriction sites: B, BssHII; M, Mlul; $\mathrm{Na}, \mathrm{Narl}$; Nt, Notl; Nr, Nrul; S, Sfil. Positions of restriction sites were determined by hybridization with GIns, Rabl, and probes specific for left (open circle) or right (solid circle) ends of the pYAC4 vector. The extent of overlap between clones was determined by comparison of restriction site patterns and by STS content analysis as shown in Table 3. The positions of GIns-ps1, ETG1.1, Rab1, and AHY1.1 are defined by the nearest restriction sites. 


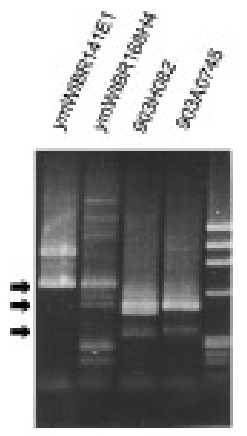

a

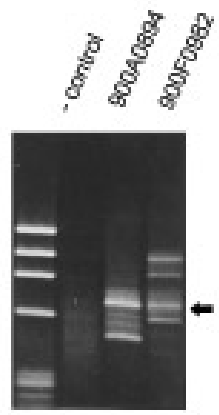

b
FIG. 4. IRS-PCR of mouse (a) and human (b) YACs from the Rab1/RAB1 regions. Total yeast DNAs containing mouse or human YACs were amplified using B1- and Alu-specific primers, respectively. Products were fractionated on a $1.5 \%$ agarose gel and stained with ethidium bromide. Overlapping PCR products are indicated by arrows.

of the contig and the genomic one is the presence of a 180-kb Narl Rabl-containing fragment in the former and a 340-kb fragment in the latter (Fig. 2). As the relevant stretch of DNA is represented two- to threefold in the YAC, chimerism is excluded as an explanation. Considering the methylation sensitivity of Narl, the most likely explanation is that the Narl site between GIns-ps1 and Rabl is methylated and hence protected in the mouse kidney DNA used. Two putative CpG islands were found in the contig, one near the methylation-sensitive Narl site, and the other near the right end of YAC $903 \mathrm{H} 082$ (Fig. 3).

Final establishment of the mouse contig and new markers. Using $B 1$ repetitive element-based PCR, characteristic amplicon band patterns could be established for each YAC (Fig. 4). The YAC ymWIBR168H4 containing the markers GIns-psl and Rabl showed the highest abundance of B1 elements (Fig. 4), indicating high gene density in this region (Bickmore and Sumner, 1989).

B1-PCR products were used to create four new physical landmarks. Seven amplification products were cloned in a shotgun manner and were sequenced. Two STSs were detectable on all four YACs and were classified as repetitive. One STS did not show any PCR prod- uct using mouse total DNA (C57BL/6] ). The remaining four STSs as well as the four STSs D11Mit79, GInsps1, Rab1, and EGT1.1 were ordered within the contig (Table 3). The STSs GIns-ps1, BY1.1, and EGT1.1 were ordered using a BY1.1-positive 100-kb P1 clone, ICRFP 703J 12189. The STS Y IL constructed by YAC end isolation gave final proof of the orientation of ymWIBR168H4, the restriction pattern of which was ambiguous, due to near symmetry of the cleavage sites. The physical order of the STSs Rabl and BY 1.2 could not determined. D11Mit79 and BY2.3 are the outermost STS markers of the mouse contig, flanking a region of approximately $600 \mathrm{~kb}$.

Mapping of the human RAB1 gene. By hybridization of the mouse $0.87-\mathrm{kb}$ CDNA RAB 1 probe to BamHI digests of a somatic cell hybrid panel, human RAB1 was mapped to Chr 2. An Alu-PCR product that is detectable on both human YACs was used to construct a new STS, AHY1 (Figs. 4b and 5b). This new marker was localized by restriction analysis and hybridization at a distance of about $70 \mathrm{~kb}$ to RAB 1. In turn, AHY 1.1 was used as a PCR marker on deletion derivatives of Chr 2 and a radiation hybrid panel (GeneBridge4). AHY1.1 was mapped to Chr 2p13.3-p14, $5.76 \mathrm{CR}_{3000}$ from the STS D2S2090 with a lod score of $>3$.

The Rabl probe was used to search for human YACs, and two RABl-containing YACs, 900A0894 and 900F 0982, were identified among 10,000 screened clones. Their restriction patterns and relative positions are shown in Fig. 6. The identification of two loci, ETG1.1 and AHY1.1, flanking the RAB1 locus allowed for the orientation of the human overlapping YACs relative to the mouse YAC contig (Fig. 7).

\section{DISCUSSION}

Our YAC study describes, for the genomes of mouse and human, the physical structure of the DNA around the gene for the ubiquitously expressed and highly conserved GTP-binding protein Rab-1. The characterized region comprises, or is in the immediate neighborhood of, the spinal atrophy gene wobbler (wr) of the mouse and is highly conserved between mouse and human (Fig. 7).

\section{TABLE 3}

\section{Characterization by STS Content of Four Mouse YACs, One Mouse P1 Clone, and Two Human YACs from the Rab1/RAB1 Regions}

\begin{tabular}{|c|c|c|c|c|c|c|c|c|c|c|c|c|c|}
\hline Species & Clone & Name & FISH & D11Mit79 & GIns-ps1 & BY 1.1 & ETG1.1 & Rab1 & BY 1.2 & Y1L & AHY 1.1 & BY2.1 & BY 2.3 \\
\hline \multirow[t]{5}{*}{ Mouse } & \multirow[t]{4}{*}{ YAC } & ymWIBR 141E 1 & C & + & + & + & + & 0 & 0 & 0 & 0 & 0 & 0 \\
\hline & & $\mathrm{ymWIBR} 168 \mathrm{H} 4$ & nc & 0 & + & + & + & + & + & + & 0 & 0 & 0 \\
\hline & & $903 \mathrm{H} 082$ & nc & 0 & 0 & 0 & + & + & + & + & + & + & + \\
\hline & & 903A0745 & nc & 0 & 0 & 0 & 0 & + & + & + & + & + & 0 \\
\hline & $\mathrm{P} 1$ & 703J 12189 & nt & & 0 & + & + & 0 & 0 & & & & \\
\hline \multirow[t]{2}{*}{ Human } & YAC & 900F 0982 & nt & & & & & + & & & + & & \\
\hline & & 900A0745 & nt & & & & & + & & & + & & \\
\hline
\end{tabular}



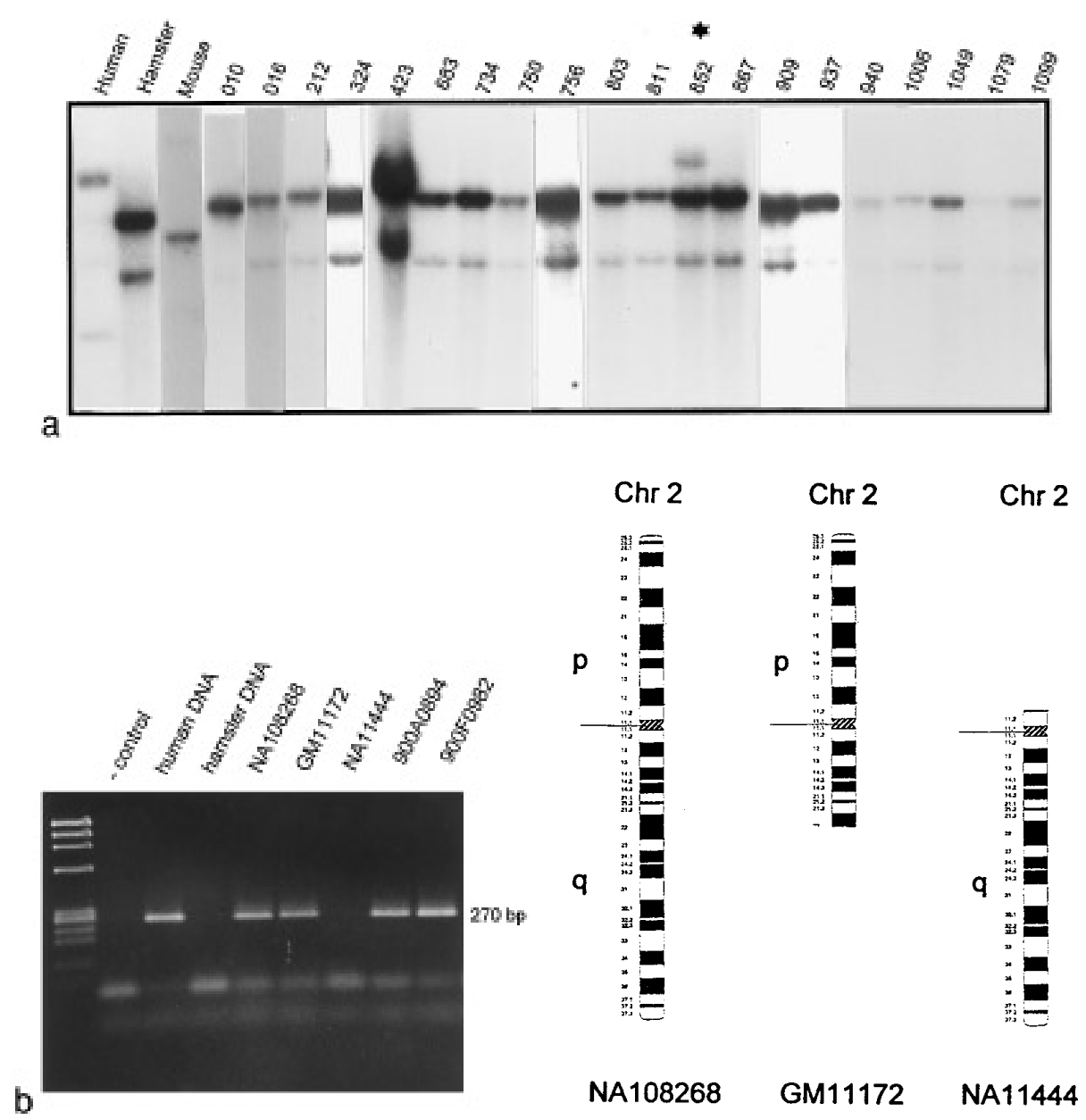

FIG. 5. Mapping of the human RAB1. (a) Southern blot using reference DNAs from human, hamster, and mouse as well as DNAs from 20 human/hamster hybrid cell lines. Ten micrograms of DNA digested with BamHI were electrophoresed, blotted, and hybridized with a mouse cDNA Rab1 probe. Hybrid cell line 852 (asterisk) was the only cell line that contained human Chr 2; it contained no other human chromosome. The blot thus shows that RAB1 maps to human Chr 2. (b) Subchromosomal localization of RAB1 using PCR on a physically linked STS, AHY1.1 (cf. Table 3). Lanes from left to right: chain length marker, $\phi$ X174 DNA, Hael II digested; control, no DNA; total human DNA; total hamster DNA; NA108268, hamster/human hybrid cell line, containing intact human Chr 2; GM11172, cell hybrid deletion derivate containing human $\mathrm{Chr} 2 \mathrm{p}$ and proximal part of $\mathrm{q}$, as shown to the right; NA11444, deletion derivate containing a proximal fragment of human Chr 2p and Chr q; 900A0894 and 900F 0982, two human YACs (cf. Table 3) containing RAB1. Two hundred nanograms of DNA was used for each PCR.

What is therelation of the wr geneto the Rabl contig? The contig around Rabl is a starting point for the search for the wr locus, as flanking markers narrow the interval for wr to $3.1 \mathrm{cM}$ around Rabl/GIns-ps1.
Among $129 \mathrm{~F} 2$ individuals with the WR phenotype, we found no recombination with D11Mit79, which is located within our Rab1 contig. Recently, 3 of 235 progeny in a C57BL-wr/NZB hybrid panel have been re-

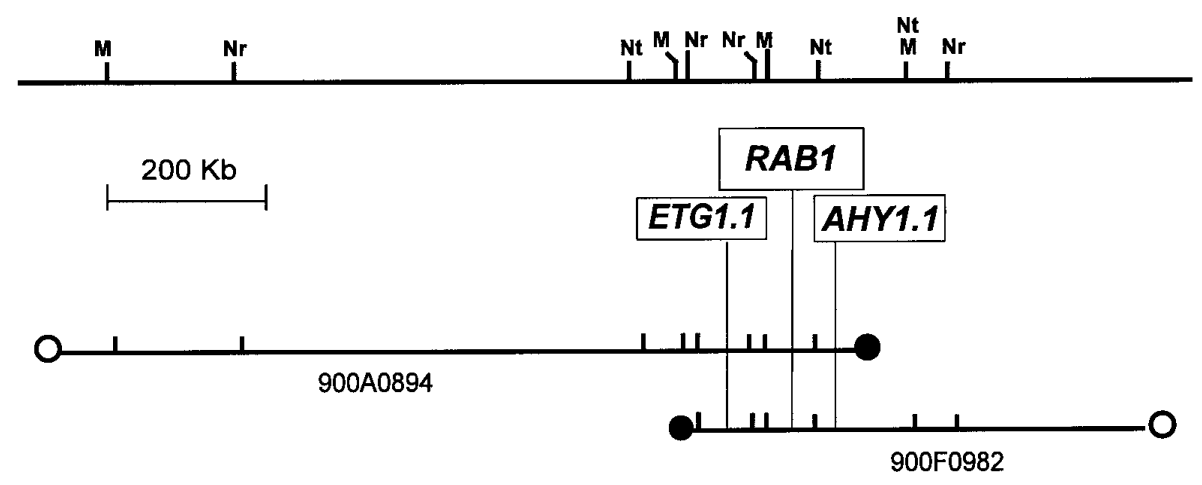

FIG. 6. Human YACs from the RAB1 region on Chr 2p. Restriction sites given above. Abbreviations as in Fig. 2, except that human gene symbols are in capitals. 
ported to show "recombination" between wr and GInsps1 (Des Portes et al., 1994). We have found one such case among 19 (C57BL-wr $\times$ NZB) F 2 and F 3 individuals. If these observations on phenotypic wildtype mice were due to recombination, the reported numbers would indicate a distance of $\geqslant 1 \mathrm{cM}$ or $\geqslant 2 \mathrm{Mb}$ between wr and GIns-ps1 and therefore between wr and Rabl. However, these recombinations need to be verified for two reasons. First, only recombinants without the WR phenotype have been reported so far. Second, the markers D11Mit162 and D11M it19 that flank wr and GInsps1 in our recombinant are not recombined. A double recombination within a distance of $<2 \mathrm{cM}$ would be extremely unlikely. Thus, the recombinants in (C57BL$w r \times N Z B$ ) crosses, defined so far only by the absence of the WR phenotype, may actually represent a suppression of the phenotype by modifier genes derived from the NZB strain. This hypothesis is supported by an observed heterogeneity in neurological and testicular symptoms in the progeny of these crosses (Augustin and J ockusch, in preparation).

Candidate genes for wr. We have tested the possibility that Rabl might be identical to the wr gene. Using genomic PCR and SSCP analysis, no difference be tween wildtype and wobbler DNA was detected ( $\mathrm{N}$. Wedemeyer, unpublished results). Due to a number of stop codons, the standard allele of the pseudogene GIns-psl cannot give rise to a protein (Bhandari et al., 1990). If at all, an abnormal mutant form of the pseudogene would be expected to exert dominant effects. Finally, enzyme el ectrophoretic patterns of cytoplasmic malate dehydrogenase have been compared between wildtype and wobbler mice. In the eight organs tested (including spinal cord and testis), no difference was found (Korthaus et al., 1996). Thus, for all three genes, Rab1, GIns-ps1, and Mor2, it is unlikely that they are directly involved in the wobbler disease.

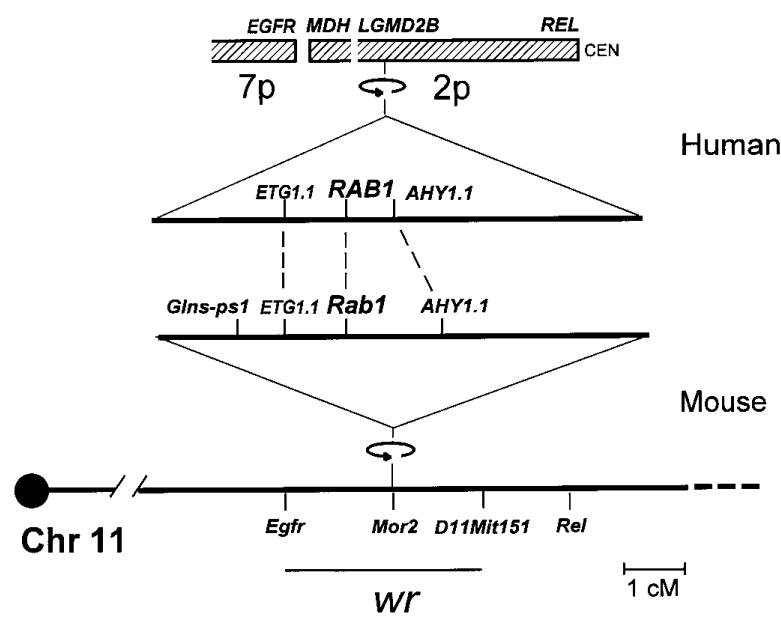

FIG. 7. Synopsis of the Rab1/RAB1 regions on mouse proximal Chr 11 and human Chr 2p. The physical maps of the YAC contigs and their homology are shown in the middle. At the present resolution, these contigs represent loci on the combined genetic/cytogenetic map of human and the genetic map of the mouse and can therefore not be oriented with respect to the centromere (indicated by relating areas). Gene symbols are as in Fig. 1.
Gene content and conservation of the Rabl/ RAB 1 re gion. The 350-kb region around GIns-ps1 and Rab1 seems to harbor a high density of genes by the following criteria: (1) It contains a putative CpG island; (2) in this region there is at least one methylation site (as defined by Narl cleavage); (3) a wide variety of B1based PCR products was obtained from this region; (4) at least one exon, ETG1.1, could be isolated from this region by exon trapping; (5) the mouse homologue of a human STS, AHY1.1, originally identified in human RAB 1-positive YAC clones, was also found in this region. The order ETG1.1-Rab1/RAB1-AHY1.1 is found in mouse and human with similar (but not identical) physical distances, indicating a high degree of conservation between these two species (Fig. 7).

We have extended the known region of conservation between mouse Chr 11 and human Chr $2 p$ by the three Ioci RAB1 and the newly discovered ETG1.1 and AHY1.1. In the wider genomic context of these, a final darification of the order of the loci between REL and MDH and of the possible conservation of gene order in addition to synteny will only be possible on the basis of a more detailed linkage analysis of the human markers.

Possible homology of LGMD2B and wr. Radiation hybrid mapping has placed the human RAB1 gene at Chr 2p13.3-p14, thus in close proximity to the gene LGMD2B for limb girdle muscular dystrophy type 2B, which has been localized to 2p13-p16 (Bashir et al., 1994; Passos-Bueno et al., 1995). Therefore, despite the classification of LGMD2B as a muscular dystrophy rather than a spinal atrophy, the possibility should be considered and tested that LGMD2B and the wobbler gene are homologous.

Outlook. In the near future, 40,000 ESTs will be available for the human genome (Boguski and Schuler, 1995). Thus, the chromosomal position of the RAB1 gene and the human YACs could be used as tools for a positional candidate approach (Collins, 1995) toward the identification of the wr gene, similar to the successful approach to identify molecularly the gene for the murine neurological mutation weaver (Patil et al., 1995).

\section{ACKNO WLEDGMENTS}

We thank Drs. H. Lehrach and S. Meier-E wert (ICRF, London/ MPI Molekulare Genetik, Berlin) for human and mouse YACs, Dr. $\mathrm{H}$. Hameister and C. Klett (University of UIm) for help with the FISH analysis, and R. Klocke and L. Koch for preparing the manuscript. This work was supported by Deutsche Forschungsgemeinschaft, SFB 223/C04.

\section{REFERENCES}

Anand, R., and Southern, E. M. (1990). Pulsed field gelelectrophoresis. In "Gelelectrophoresis of Nucleic Acids: A Practical Approach" (P. Rickwood and B. D. Hames, Eds.), pp. 101-122, IRL Press, Oxford.

Ball, S. T., Moseley, H. J ., and Peters, J . (1994). Mor2, supernatant malate dehydrogenase, is linked to wa2 and $\mathrm{H}$ ba on mouse chromosome 11 in a region of homology with human chromosome $2 \mathrm{p}$. Genomics 24: 399-400. 
Bashir, R., Strachan, T., Keers, S., Stephenson, A., Mahjneh, I., Marconi, G., Nashef, L., and Bushby, K. M. D. (1994). A genefor autosomal recessivelimb-girdle muscular dystrophy maps to chromosome 2p. Hum. Mol. Genet. 3: 455- 457.

Bates, G. P., Valdes, J ., Hummerich, H., Baxendale, S., Le Paslier, D. L., Monaco, A. P., Tagle, D., MacDonald, M. E., Altherr, M., Ross, M., Brownstein, B. H., Bentley, D., Wasmuth, J . J ., Gusella, J . F., Cohen, D., Collins, F., and Lehrach, H. (1992). Characterization of a yeast artificial chromosome contig spanning the Huntington's disease gene candidate region. Nature Genet. 1: 180- 187.

Berry, R., Stevens, T. J ., Walter, N. A. R., Wilcox, A. S., Rubano, T., Hopkins, J. A., Weber, J., Goold, R., Soares, M. B., and Sikela, J . M. (1995). Gene-based sequence-tagged-sides (STSs) as the basis for a human gene map. Nature Genet. 10: 415- 423.

Bhandari, B., Beckwith, K., and Miller, R. E. (1988). Cloning, nucleotide sequence, and potential regulatory elements of the glutamine synthetase gene from 3T3-L1 adipocytes. Proc. Natl. Acad. Sci. USA 85: 5789- 5793.

Bhandari, B., Roesler, W. J ., DeLisio, K. D., Klemm, D. J ., Ross, N. S., and Miller, R. E. (1990). A functional promoter flanks an intronless glutamine synthetase gene. J . Biol. Chem. 266: 77847792.

Bickmore, W. A., and Sumner, A. T. (1989). Mammalian chromosome banding-An expression of genome organization. Trends Genet. 5: 144- 148.

Bloom, M. L., Lee, B. K., Birkemeier, C. S., Ma, Y., Zimmer, W. E., Goodman, S. R., Eicher, E. M., and Barker, J . E. (1992). Brain $\beta$ spectrin isoform 235 (Spnb-2) maps to mouse chromosome 11. Mamm. Genome 3: 293- 295.

Boguski, M. S., and Schuler, G. D. (1995). ESTablishing a human transcript map. Nature Genet. 10: 369- 370.

Brownell, E., O'Brien, S. J ., Nash, W. G., and Rice, N. (1985). Genetic characterization of human c-rel sequences. Mol. Cell. Biol. 5: 28262831.

Buckler, A. J ., Chang, D. D., Graw, S. L., Brook, J . B., Haber, D. A., Sharp, P. A., and Housman, D. E. (1991). Exon amplification: A strategy to isolate mammalian genes based on RNA splicing. Proc. Natl. Acad. Sci. USA 88: 4005-4009.

Collins, F. S. (1995). Positional cloning moves from perditional to traditional. Nature Genet. 9: 347-350.

Cox, R. D., Whittington, J ., Shedlovsky, A., Connelly, C. S., Dove, W. F., Goldsworthy, M., Larin, Z., and Lehrach, H. (1993). Detailed physical and genetic mapping in the region of plasminogen, D17Rp17e, and quaking. Mamm. Genome 4: 687-694.

Des Portes, V., Coulpier, M., Melki, J ., and Dreyfus, P. A. (1994). Early detection of mouse wobbler: A model of pathological motoneurone death. Neuro Report 5: 1861- 1864.

Duchen, L. W., and Strich, S. J . (1968). An hereditary motor neuron disease with progressive denervation of muscle in mouse: The mutant "wobbler". J . Neurol. Neurosurg. Psychiatry 31: 535- 542.

Green, E. D., and OIson, M. V. (1990). Systematic screening of yeast artificial-chromosome libraries by use of the polymerase chain reaction. Proc. Natl. Acad. Sci. USA 87: 1213- 1217.

Hamvas, R. M. J ., Larin, Z., Brockdorff, N., Rastan, S., Lehrach, H., Chartier, F. L., and Brown, S. D. M. (1993). YAC clone surrounding the Zfx and Pola loci on the mouse $X$ chromosome. Genomics 17: 52- 58 .

Hunter, K. W., Ontiveros, S. D., Watson, M. L., Stanton, V. P., J r.,
Gutierrez, P., Bhat, D., Rochelle, J., Graw, S., Ton, C., Schalling, M., Aburantani, H., Brown, S. D. M., Seldin, M. F., and Housman, D. E. (1994). Rapid and efficient construction of yeast artificial chromosome contigs in the mouse genome with interspersed repetitive sequence PCR (IRS-PCR): Generation of a 5-CM, > 5 megabase contig on mouse chromosome 1. Mamm. Genome 5: 597-607.

Kaupmann, K., Sendtner, M., Stöckli, K. A., and J ockusch, H. (1991). The gene for ciliary neurotrophic factor (CNTF) maps to murine chromosome 19, and its expression is not affected in the hereditary motoneuron disease "wobbler" of the mouse. Eur. J . Neurosci. 3: $1182-1186$.

Kaupmann, K., Simon-Chazottes, D., Guénet, J .-L., and J ockusch, H. (1992). Wobbler, a mutation affecting motoneuron survival and gonadal functions in the mouse, maps to proximal chromosome 11. Genomics 13: 39- 43.

Korthaus, D., Wedemeyer, N., Wiegand, Ch., and J ockusch, H. (1996). The gene for cytoplasmatic malate dehydrogenase, Mor2, is closely linked to the wobbler spinal muscular atrophy gene (wr). Mamm. Genome, in press.

Kusumi, K., Smith, J . S., Segre, J . A., Koos, D. S., and Lander, E. S. (1993). Construction of a large-insert yeast artificial chromosome library of the mouse genome. Mamm. Genome 4: 391- 392.

Larin, Z., Monaco, A. P., and Lehrach, H. (1991). Yeast artificial chromosome libraries containing large inserts from mouse and human DNA. Proc. Natl. Acad. Sci. USA 88: 4123- 4127.

Lengeling, A., Zimmer, W. E., Goodman, S. R., Ma, Y., Bloom, M. L., Bruneau, G., Krieger, M., Thibault, J ., Kaupmann, K., and J ockusch, H. (1994). Exclusion of two candidate genes, Spnb-2 and Ddc, for the wobbler spinal muscular atrophy gene on proximal mouse chromosome 11. Mamm. Genome 5: 163- 166.

Nowak, R. (1995). Genome mappers have a hot time at Cold Spring Harbor. Science 268: 1134- 1135.

Passos-Bueno, M. R., Bashir, R., Moreira, E. S., Vainzof, M., Marie, S. K., Vasquez, L., I ughetti, P., Bakker, E., Keers, S., Stephenson, A., Strachan, T., Mahneh, E., Weissenbach, J., Bushby, K., and Zatz, M. (1995). Confirmation of the $2 p$ locus for the mild autosomal recessive limb-girdle muscular dystrophy gene (LGMD2B) in three families allows refinement of the candidate region. Genomics 27: 192- 195.

Patil, N., Cox, D. R., Bhat, D., Faham, M., Myers, R. M., and Peterson, A. S. (1995). A potassium channel mutation in weaver mice implicates membrane excitability in granule cell differentiation. Nature Genet. 11: 126- 129.

Polaina, J ., and Adam, A. C. (1991). A fast procedure for yeast DNA purification. Nucleic Acids Res. 19: 5443.

Silverman, G. A., Ye, R. D., Pollock, K. M., Sadler, J . E., and Korsmeyer, S. J . (1989). Use of yeast artificial chromosome clones for mapping and walking within human chromosome segment 18q21.3. Proc. Natl. Acad. Sci. USA 86: 7485- 7489.

Walter, M. A., Spillett, D. J ., Thomas, P., Weissenbach, J ., and Goodfellow, P. A. (1994). A method for constructing radiation hybrid maps of whole genomes. Nature Genet. 7: 22-28.

Wichmann, H., Disela, C., Haubruck, H., and Gallwitz, D. (1989). Nucleotide sequence of the mouse yptl gene encoding a ras-related GTP-binding protein. Nucleic Acids Res. 17: 6737-6738.

Wichmann, H., J ockusch, H., Guénet, J .-L., Gallwitz, D., and Kaupmann, K. (1992). The mouse homolog to the ras-related yeast gene YPT1 maps on chromosome 11 close to the wobbler (wr) locus. Mamm. Genome 3: 467-468. 